\title{
THE STRATEGIC DEVELOPMENT OF TERRITORIES BASED ON OVERCOMING THE REGIONAL ASYMMETRIES
}

\author{
๑2019 ZABARNA E. M.
}

UDC 332.146.2

JEL: R11; R58

Zabarna E. M. The Strategic Development of Territories Based on Overcoming the Regional Asymmetries

Modern processes of reforming the relationships between the "center» and the "region» as well as the need to create self-sufficient territorial communities require deep researches with the scientifically sound approaches to the formation of regional policy along with Ukraine's development strategy on the basis of creating legal and financial preconditions for self-government, which is the purpose of this article. The main reasons for the increase in asymmetry in the regional development are defined, one of the reasons which are highlighted is that regions with diversely structured economy adapt to the new economic conditions differently. It is shown that interregional differences are a reflection of the increasing differentiation between the economic (differences in ownership and sectors of the economy) and the social (different groups of the population) constituents. An analysis of the development of Ukraine's regions is carried out in terms of GDP, the level of competitiveness in industrial production, the innovation activity of the real sector, the human resources, and operation of the labor market. It is indicated that the main task of reforming the regional development of the State should be the creation of regional democracy as a system that efficiently and consistently enables the State with a complex regional structure, territorial communities with different cultural and linguistic compositions to live in harmony and economic well-being. Particular attention should be focused on: providing conditions for the regional economic and budgetary self-sufficiency; creating the conditions for inflows of investment to restructure regional economies; creating a new communal utilities system involving both regional and local government bodies; reforming the fiscal-budgetary and tax system in accordance with the needs of regions; developing plans and strategies for the development of individual territories; settling the rules and regulations of the land market; a clear definition of the role and place of local authorities in the management of public property. Keywords: regional development, strategy, territorial communities, restructuring, resource mobilization, differentiation, potential.

DOl: https://doi.org/10.32983/2222-4459-2019-7-101-107

Fig.: 2. Tabl.: 2. Bibl.: 16 .

Zabarna Eleonora M. - D. Sc. (Economics), Professor, Head of the Department of Economic Systems and Management of Innovation Development, Odesa National Polytechnic University (1 Shevchenka Ave., Odesa, 65044, Ukraine)

E-mail: eleonoraz@ukr.net

УДК 332.146 .2

JEL: R11; R58

Забарна Е. М. Стратегічний розвиток територій на основі подолання регіональних асиметрій

Сучасні процеси реформування відносин мін «центром» $і$ «регіоном», a також необхідність формування самодостатніх територіальних громад потребують глибоких досліджень та науково обгрунтованих підходів до формування регіональної політики та стратегії розвитку території України на основі створення правових і фінансових складових самоврядування, що іє метою даної статті. Визначено основні причини посилення асиметрії в регіональному розвитку, серед яких виділено, що регіони з різною структурою економіки по-різному адаптуються до нових умов господарювання. Показано, що міжрегіональні відмінності є відображенням все більшої диреренціації між економічною (різниця у формах власності та секторах економіки) та соціальною (різні групи населення) складовими. здійснено аналіз розвитку регіонів України за показниками: ВРП, рівня конкурентоспроможності в промисловому виробництві, інноваційної активності реального сектора, кадрового потенціалу та функціонування ринку праці. Показано, що головним завданням реформування регіонального розвитку держави має стати регіональна демократія як система, що ефективно та послідовно дає можливість державі зі складною регіональною структурою, територіальним громадам з різним культурно-мовним складом жити в гармонії та економічному благополуччі. Особливу увагу при цьому необхідно зосередити на: забезпеченні умов для регіональної економічної та бюджетної самодостатності; створенні умов для притоку інвестицій з метою реструктуризації регіональних економік; створенні нової системи управління комунальним господарством за участі регіональних і місцевих органів влади; ресормі фінансово-бюджетної та податкової системи відповідно до потреб регіонів; розробці планів та стратегій розвитку окремих територій; урегулюванні норм і правил функціонування ринку землі; чіткому визначенні ролі та місия місцевих органів влади в управлінні державною власністю.
УДК 332.146.2

JEL: R11; R58

Забарная Э. Н. Стратегическое развитие территорий на основе преодоления региональных асимметрий

Современные процессы реформирования отношений между «центром» и «регионом», а также необходимость формирования самодостаточных территориальных громад требуют глубоких исследований и научно обоснованных подходов к формированию региональной политики и стратегии развития территорий Украины на основе создания правовых и финансовых предпосылок самоуправления, что и является целью данной статьи. Определены основные причины усиления асимметрии в региональном развитии, среди которых выделено, что регионы с разной структурой экономики по-разному адаптируются к новым условиям хозяйствования. Показано, что межрегиональные различия являются отображением все большей диффференциации между экономической (разница в формах собственности и секторах экономики) и социальной (разные группы населения) составляющими. Проведен анализ развития регионов Украины по показателям: ВРП, уровня конкурентоспособности в промышленном производстве, инновационной активности реального сектора, кадрового потенциала и функционирования рынка труда. Показано, что главным заданием ресоормирования регионального развития государства должно стать создание региональной демократии как системы, которая эфффективно и последовательно дает возможность государству со сложной региональной структурой, территориальным громадам с разным культурно-языковым составом жить в гармонии и экономическом благополучии. Особое внимание при этом необходимо сосредоточить на: обеспечении условий для региональной экономической и бюджетной самодостаточности; создании условий для притока инвестиций с целью реструктуризации региональных экономик; создании новой системы управления коммунальным хозяйством с участием региональных и местных органов власти; реформе финансово-бюджетной и налоговой системы в соответствии с потребностями регионов; разработке планов и стратегий развития отдельных территорий; урегулировании норм и правил функционирования рынка земли; четком определении роли и места местных органов власти в управлении государственной собственностью. 
Ключові слова: регіональний розвиток, стратегія, територіальні громади, реструктуризація, мобілізація ресурсів, диференціація, потенціал.

Puс.: 2. Табл.: 2. Бібл.: 16.

Забарна Елеонора Миколаївна - доктор економічних наук, професор, завідувачка кафедри економічних систем та управління інноваційним розвитком, Одеський національний політехнічний університет (просп. Шевченка, 1, Одеса, 65044, Україна)

E-mail: eleonoraz@ukr.net
Ключевые слова: региональное развитие, стратегия, территориальные громады, реструктуризация, мобилизация ресурсов, диффреренциация, потенциал.

Рис.: 2. Табл.: 2. Библ.: 16.

Забарная Элеонора Николаевна - доктор экономических наук, профессор, заведующая кафедрой экономических систем и управления инновационным развитием, Одесский национальный политехнический университет (просп. Шевченко, 1, Одесса, 65044, Украина)

E-mail: eleonoraz@ukr.net
$\mathrm{T}$ he economy of Ukraine based on the new system of regional distribution is a completely new phenomenon leading to a fundamental change in the functioning of the economic systems and society of the country as a whole. The purpose of optimizing the territorial structure is to create an effective system of management in new administrative territories that can provide favorable conditions for people's lives and opportunities for sustainable social and economic development of all regions through the rational use of their potential. Today, Ukraine faces the need to introduce significant changes in all spheres of social development, including the regional policy. The content of these changes will be defined as the level of awareness of society and government of the essence of political and socioeconomic processes that have taken place in the country over the past decade as well as the choice of ideology and model of development of the country as a whole, and the interrelations of the center and the regions.

Today, the development of Ukraine as a whole and its individual regions in particular is characterized by contradictions and unpredictability. That is why there is an urgent need for a real assessment of achievements, definition of the prospects and timing of the implementation of the goals set, determination of levers and resources required.

The logic of studying a region from a systemic perspective requires not only describing the process of development of the region itself, but also studying the structure and properties of the regional economy, since the main forces and development prospects lie in its deep layers. Regional economic systems are characterized by a combination of social, economic, environmental, informational, and other components, the presence of many complex elements, a wide variety of interconnections, and the circulation of large flows of material, financial, and informational resources [1]. Traditional economic theories are often mistaken in their attempts to explain the phenomena of reality. On the one hand, the real world has become dramatically complex, more volatile and unstable in recent decades. On the other hand, the traditional economic toolkit has its own limitations nonlinear and unstable processes (e.g., regular and irregular fluctuations), which in the traditional analysis are considered as random or minor phenomena [2, p. 208].

Therefore, when considering problems related to evolution and qualitative changes in nonlinear and unstable socioeconomic systems, such as Ukrainian regions, specialists are increasingly turning to new directions of interdisciplinary analysis and new areas of economic theory, including synergistic economics and the theory of self-organization [3]. If the basis of the systems analysis is the principle of systematicity, then the basis of the theory of self-organization is the principle of development [4, p. 112]. Both principles complement each other and in fact form a certain unity, which manifests itself in the process of knowledge as a unity of selforganization and systemic research.

The problems of forming theoretical and methodological foundations of socioeconomic development of the regions and shaping the policy of their transformation under the current conditions are highlighted in the scientific works of a number of researchers, namely: M. Butko [5], I. Vakhovych [6], V. Heyets [7], N. Kuharskaya [2], V. Pavlov [8], D. Stechenko [9], and others. At the same time, modern processes of reforming the relations between the center and a region as well as the need to form independent and self-sufficient territorial communities require substantial research and scientifically based approaches to shaping the regional policy and development strategy of the territories of Ukraine on the basis of creating legal and financial prerequisites for selfgovernance of the regions and territorial communities, which is the main aim of the article.

$\mathrm{R}$ egional economic systems belong to the class of complex systems capable of self-organization, in which the process of self-regulation and selfdevelopment is realized, and, therefore, the methods of systems analysis can be effectively used for their research. In recent years, science has greatly strengthened the idea that complex ecological and economic, and socio-cultural phenomena can be represented as a single integrated dynamic system in which the main role is played by the phenomena of self-organization.

A strategy for the development of a territory can be elaborated provided that there is a clear understanding of the characteristics of the placement of productive forces and the nature of the involvement of economic units in the entire complex of the regional and national economy. However, the boundaries of a territory may not coincide with the administrative boundaries. In addition, changes in the state of affairs may lead to those in the boundaries of territories as objects of economic analysis. It is also important to consider transnational economic relations. 
Local government reform significantly updates the need for greater autonomy of the regions in the formation of management decisions, i. e., decentralization [10]. Extension of the rights, opportunities and responsibilities of the regions is accompanied by a number of positive effects. Among them are the following: a) regional authorities will be able to more fully take into account the specific features of the region, focusing on the maximum use of local resources; b) decisions are made with greater efficiency; c) the degree of inhabitants' activity substantially increases, which creates conditions for the achievement of synergetic social effects (the formation of a social agreement), etc. The centrifugal trends in the development of the regions do not contradict the general laws of development of complex socio-economic systems: under conditions of the growing inadequacy of the systematic organization of the state of the environment, the weakening of the "center-region" ties results in an increase in the adaptability of the system. As a result, the required level of performance is achieved. Consequently, from the point of view of the synergetic paradigm, an important sign of transformation is the evolution of forms of system organization, which is characterized, in particular, by a relative weakening of the structure of internal organizational relationships at certain hierarchical levels. This increases the ability of system elements to respond adequately and flexibly to changes in the environment.

$\mathrm{U}$ kraine's regions differ considerably. Therefore, there is a significant difference in their economic indicators. Recently, the differentiation has intensified due to a number of reasons: regions with different economic structures adapt to different conditions of management in different ways. In general, interregional differences are a reflection of the increasing differentiation between economic (the difference between forms of ownership and sectors of the economy) and social (different population groups) components in the regions. In 2017 , the range of variation in the indicators of the gross regional product was 25 times (Kyiv - UAH 451700 million, Chernivtsi region - UAH 18506 million) [11]; the range of variation in the volume of capital investments was almost 40 times (Kyiv - 96810.7 million UAH, Chernivtsi region - 2444.9 million UAH) [12].

In recent years, there has been observed a low competitiveness of the regions in foreign markets; a disbalance of the domestic market, economic exchange among the regions; a significant reduction in their output due to industries manufacturing final consumption products (first of all, machine building). As a result of the military conflict in the east of Ukraine, there were destroyed the close economic ties among the regions where the metallurgical, coal mining industry of the country was concentrated (namely, Donetsk, Dnipropetrovsk, Zaporizhzhia and Luhansk regions) as well as everything required for their functioning [13]. They formed the most powerful financial and industrial group in the country that dictated their economic and political conditions. The fundamental change in the ownership structure, which influenced the differentiation of the economic development at the regional level as a result of introducing new forms of management and reducing the share of the state sector of the economy, has led to the impossibility of direct administrative influence of local self-government bodies on business entities and the loss of direct intervention of authorities. In view of this, it is possible to draw conclusions about who really rules in each region.

$\mathrm{M}$ ost regions are specialized in raw materials or manufacture intermediate products, their economic potential is determined by one or two branches. Almost half of the gross value added in 2017 was created in four regions: the city of Kyiv (21.3\%), Dnipropetrovsk region (11.4\%), Kharkiv region (6.2\%). An increase in the regional asymmetry in the investment in fixed capital will have an extremely negative impact on the future structure of the economy of most Ukraine's regions. This results in poor prospects for the domestic production and placement of foreign capital. Thus, in $2008,41.1 \%$ of all foreign direct investment was placed in the city of Kyiv, and in 2016, the capital accounted for more than $50 \%$. In 13 regions, the share of foreign direct investment does not exceed $1 \%$ of the total indicator for Ukraine. These are mainly regions that have potential (but not used) opportunities for agricultural development, demonstrate the decline of industry and low level of service sector development. A similar trend is observed in the distribution of credit resources of Ukrainian commercial banks: half of the loans granted to business entities are concentrated in Kyiv and Kyiv region [14].

The regions' economy adapted differently to the recent changes, and this has affected the regional labor markets. According to regional statistics, the average unemployment rate in early 2016 was $9.1 \%$, at the beginning of $2014-9.3 \%$, and in early $2013-7.2 \%$. On average, the supply of labor exceeds the demand 19 times in the regions, for example, in Zaporizhzhia region - 185, and in the city of Kyiv, on the contrary, only 4 times. From 20 to $50 \%$ of the unemployed in the regions do not work for more than 1 year. An important indicator of the standard of living is the income of the population. The difference in the existing level of per capita income among individual regions is more than 5 times (including Kyiv). In 2017, the gap in the level of per capita income among individual regions (excluding Kyiv) is over $76 \%$, although, according to the international standards, it should not exceed $20 \%$ [15].

In the process of decentralization, it is necessary to create legal and financial prerequisites for establishing self-governance in regions and territorial communities. Therefore, when reforming the system of financial relations between the regions and the center, it is important to ensure such conditions for their functioning that they could have sufficient potential for expanded reproduc- 
tion and be independent in terms of the economy and budget. Economic goals that can stimulate the inflow of financial resources in the most dynamic regions, maximally accelerate the growth of the national economy and restructuring of the economy of individual regions must be brought to the forefront. It is important to create a new system for managing the utilities sector of the economy with the participation of regional and local self-government bodies, reform the fiscal and tax system in accordance with the needs of the regions. The improvement of the practice of territorial planning and programming, the elaboration of state target programs for the development of individual regions and territories (in particular medium and long-term territorial planning) will become an important factor in increasing the role of local budgets as a structural element in the system of such planning; forming a new system for governance of the public sector with a clear definition of the role and place of local self-government bodies in management of state property.

A new impetus should be given to the development of small mono-functional towns, whose structural basis is one or two enterprises. Currently, there are 352 small towns in Ukraine, of which 122 are mono-functional ones. Small towns comprise 19\% of the urban population of Ukraine. Against the background of the general tendency of decrease in the population of small Ukrainian towns, there observed a positive natural increase in population $(1.1-1.3 \%)$ and its significant increase (1.7-3.6\%) due to migration [16]. Given the actual stoppage of production in such towns, they should become objects of special state support.

The development of depressed regions, which were once characterized by high potential of industrial production and sufficiently developed infrastructure is of great importance. At the same time, the object of state support should be not regional management structures but the population and enterprises. It is necessary to ensure that targeted state support be provided to regions, individual territorial communities suffering from structural transformations, as well as to underdeveloped territories, whose socio-economic indicators are significantly lower than the national average. In this aspect, there are two key issues of self-sufficiency: financial and spatial. All countries of the world are building their policy of local self-government based on the fact that land and other real estate are local economic resources that are the basis of self-sufficiency.

Land is the main material and financial base of local self-government. At the same time, in Ukraine, territorial communities lose funds due to the lack of rights to own the land, in particular due to the poor filling of local budgets with land payments; the absence of legal norms and mechanisms for collecting real estate taxes, revenues from real estate sale and land contracts, etc. In addition, the lack of a land market impedes the development of the economic system at the regional and local levels. The land owned by the territorial communities should become an economic asset and be used by the local self-government bodies not for the enrichment of individual officials but for the development of the territorial community.

Developed countries, for this purpose, create special asset management companies, which the community can join as a shareholder by means of self-government bodies. Such companies, in the most efficient and transparent manner, implement development of project management and have tools for professional management of rational use of territorial assets.

$\mathrm{T}$ he place and role of the territorial organization of government and development of local selfgovernment in the system of regional policy is now debatable. The conducted analysis of foreign experience shows that these problems are mainly related to constitutional reforms and issues of state-building. It is necessary to carry out constructive scientific work on the gradual transformation of the state structure of Ukraine in the direction of enhancing the role of the regions in addressing issues of socio-economic development, further decentralization of governance through both deconcentration and transfer or delegation of certain functions of executive authority to local self-government bodies at local levels. In the future, it is possible to reform the system of administrative and territorial division by increasing basic administrative territories, bring their boundaries in line with the territorial communities - subjects of the right to local self-government, which will enable to significantly reduce the number of these entities and form a self-sufficient territorial community. To ensure the further advance in local self-government, strategies for the development of Ukrainian territories should envisage the formation of a primary subject of local self-government a self-sufficient territorial community that would have the material and financial resources sufficient for the realization of the tasks and functions entrusted to it by the Constitution and laws of Ukraine. The main characteristics of forming the united territorial communities (UTCs) of Odesa region are presented in Tbl. 1 and Tbl. 2.

Self-sufficiency, financial capacity of UTCs will, at some stage, cause a change in the constitutional nature of local self-government bodies of the regional level - regional councils, functioning as the bodies that represent the common interests of territorial communities of villages, towns and cities, can be transformed into representative bodies of the territorial community of the regions. This involves establishing executive bodies of the region and gradually devolving certain powers to the regional state administrations, which should be accompanied by transferring the personnel, corresponding material and financial resources.

In general, the strategy of territorial development based on overcoming regional asymmetries and their financial support has positive effects, which are accumulated in Fig. 1, and require solving a number of problem issues (Fig. 2). 
Characteristics of the UTCs of Odesa region

\begin{tabular}{|c|c|c|c|c|c|c|c|}
\hline \multirow[b]{2}{*}{$\begin{array}{l}\text { The name of the united } \\
\text { territorial community }\end{array}$} & \multirow[b]{2}{*}{ 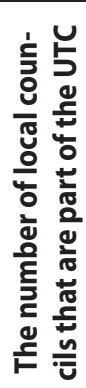 } & \multirow[b]{2}{*}{ 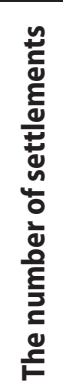 } & \multirow[b]{2}{*}{ 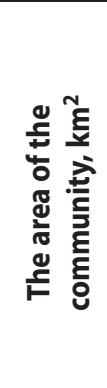 } & \multirow[b]{2}{*}{ 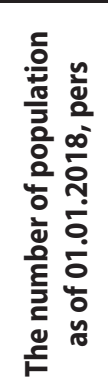 } & \multicolumn{2}{|c|}{ Including } & \multirow{2}{*}{ 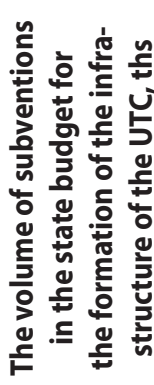 } \\
\hline & & & & & $\begin{array}{l}\text { local popu- } \\
\text { lation, pers }\end{array}$ & $\begin{array}{l}\text { rural popu- } \\
\text { lation, pers }\end{array}$ & \\
\hline Balta UTC & 17 & 28 & 854.6 & 32943 & 18993 & 13950 & 19652.6 \\
\hline Biliaivka UTC & 2 & 3 & 193.0 & 13546 & 11891 & 1655 & 3510.8 \\
\hline Velykomykhailivka UTC & 9 & 25 & 494.4 & 12788 & 5638 & 7150 & 10860.1 \\
\hline Krasnoselsk UTC & 2 & 7 & 246.6 & 10932 & $x$ & 10932 & 9492.7 \\
\hline Marazliivka UTC & 3 & 8 & 252.1 & 6018 & $x$ & 6018 & 6850.3 \\
\hline Rozkvit UTC & 3 & 14 & 236.8 & 4315 & $x$ & 4315 & 5694.3 \\
\hline Tuzly UTC & 2 & 7 & 101.0 & 2593 & $x$ & 2593 & 2845.2 \\
\hline Novokal-chevo UTC & 2 & 6 & 207.8 & 2315 & $x$ & 2315 & 4182.7 \\
\hline Total in the region & 40 & 98 & 2586.3 & 85450 & 36522 & 48928 & 6318.7 \\
\hline
\end{tabular}

Table 2

Financial capacity of the UTCs of Odesa region

\begin{tabular}{|l|c|c|c|c|c|c|}
\hline $\begin{array}{c}\text { The name of the } \\
\text { united territorial } \\
\text { community }\end{array}$ & $\begin{array}{c}\text { Population, } \\
\text { ths people }\end{array}$ & $\begin{array}{c}\text { Per capita } \\
\text { income, UAH }\end{array}$ & $\begin{array}{c}\text { Basic/reverse } \\
\text { subsidy, } \\
\text { UAH ths }\end{array}$ & $\begin{array}{c}\text { Share of bud- } \\
\text { get subsidiza- } \\
\text { tion (financial } \\
\text { dependence } \\
\text { on the state } \\
\text { budget), }\end{array}$ & $\begin{array}{c}\text { Share of de- } \\
\text { expenditures } \\
\text { (capital ex- } \\
\text { penditures), } \\
\text { UAH ths. } \\
\text { velopment } \\
\text { expenditures } \\
\text { in the UTC's } \\
\text { own resources } \\
\text { (without sub- } \\
\text { ventions), } \%\end{array}$ \\
\hline Biliaivka UTC & 13.5 & 1956 & -636.0 & 0 & 3309.4 & 12.5 \\
\hline Krasnoselsk UTC & 10.9 & 1946 & 1556.1 & 7 & 8591.06 & 37.6 \\
\hline Tuzly UTC & 2.6 & 1743 & 886.8 & 16 & 933.9 & 17.3 \\
\hline Marazliivka UTC & 6.0 & 1423 & 1903.0 & 18 & 0.0 & 0.0 \\
\hline Novokalchevo UTC & 2.3 & 1415 & 248.4 & 7 & 0.0 & 0.0 \\
\hline $\begin{array}{l}\text { Velykomykhailivka } \\
\text { UTC }\end{array}$ & 12.8 & 1187 & 2612.3 & 15 & 4321.1 & 24.3 \\
\hline Balta UTC & 32.9 & 1166 & 7092.4 & 16 & 1965.0 & 4.3 \\
\hline Rozkvit UTC & 4.3 & 116 & 1080.3 & 24 & 0.0 & 0.0 \\
\hline Total in the region & 85.5 & 1452 & 14743.3 & 13 & 19121.1 & 12.0 \\
\hline
\end{tabular}

\section{CONCLUSIONS}

The main task of reforming the regional development of the state should be the creation of regional democracy as a system that effectively and consistently enables a country with a complex regional structure, territorial communities, different cultural and linguistic communities to live in harmony and economic well-being.

Thus, the reform of the "center-region" relations in the direction of decentralization is an objective process that provides additional opportunities for an effective transformation the national economy. However, they are manifested when regions are progressing at the same or adequate pace, when there is normal (economic) interregional competition and integration, and political ideas that are responsive to both regional and national interests are implemented. Otherwise, there is an increase in regional imbalances, which is happening today in the Ukrainian economy. Regional asymmetries are manifested in two aspects: the regional socio-economic divergence (here, regional divergence is understood not simply and not only as the gap in the levels of the accepted standard of living or in the indicators of the gross regional product 
The ability to take into account the specifics of a region

to the fullest extent, directing efforts of local

self-government bodies towards the maximal use

of local resources.

A greater efficiency in decision-making.

The degree of inhabitants' activity substantially increases,

creating conditions for achieving synergistic social effects

Fig. 1. The main positive effects of the strategy of forming a financially capable UTC

\begin{tabular}{|c|}
\hline PROBLEMS TO BE SOLVED \\
\hline $\begin{array}{l}\text { Clear regulation of the land market and enforcement } \\
\text { of laws related to it. } \\
\text { Overcoming contradictions in the functions of governance } \\
\text { between local self-government bodies and regional } \\
\text { administrations. } \\
\text { The formation of a new system for managing the utilities } \\
\text { sector of the economy with the participation of local } \\
\text { self-government bodies; reformation of the fiscal and tax } \\
\text { system in accordance with the needs of a region }\end{array}$ \\
\hline
\end{tabular}

\section{Fig. 2. Key problems of the strategy of forming a financially capable UTC in Ukraine}

per capita; rather, it means a qualitative imbalance in the coordinate system of development of regions) and regional interests, tools for achieving goals.

\section{LITERATURE}

1. Забарна Е. М. Стратегування як інструмент соціально-економічного розвитку реального сектору регіонів // Випереджаючий інноваційний розвиток: теорія, методика, практика : монографія / за ред. Ілляшенко Н. С. Суми : Територія, 2018. С. 93-115.

2. Кухарская Н. А. Стратегические приоритеты трансформации экономики регионов Украины: тенденции, формы, механизмы : монография. Одесса : ИПРЭЭИ НАН Украины, 2010.519 c.

3. Забарна Е. М., Чередниченко В. А. До питання формування правових та фінансових передумов самоуправління регіонів та територіальних громад. Економічний форум. 2018. № 1. С. 62-67.

4. Мельник Л. Г. Экономика развития :учебник. Сумы : Университетская книга, 2013. 784 с.

5. Бутко М. П., Попело О. В. Комерціалізація результатів науково-технічної діяльності в умовах поглиблення інтеграційних процесів. Проблеми і перспективи економіки та управління. 2015. № 1. С. 7-20.

6. Вахович І. М., Гавура В. О. Формування конкурентоспроможної економіки регіонів України : монографія. Луцьк : Надстир'я, 2013.

7. Трансформація моделі економіки України. Ідеологія, протиріччя, перспективи : монографія / за ред. Гейця В. М.. Київ : Логос, 1999. 497 с.

8. Павлов В. І. Політика регіонального розвитку в умовах ринкової трансформації: теоретико-методологіч- ні аспекти та механізми реалізації : дис. ... д-ра екон. наук. Луцьк, 2000.

9. Стеченко Д. М. Розміщення продуктивних сил і регіоналістика : навч. посіб. Київ : Вікар, 2001. 374 с.

10. Закон України «Про стимулювання розвитку регіонів» від 08.09.2005 р. № 2850-IV. URL: https://zakon.rada.gov. ua/laws/show/2850-15

11. Валовий регіональний продукт (2004-2018). URL: http://www.ukrstat.gov.ua/operativ/operativ2008/vvp/vrp/ vrp2018_u.zip

12. Капітальні інвестиції за регіонами за 2017 рік. URL: http://www.ukrstat.gov.ua/operativ/operativ2016/ibd/iki_reg/ iki_reg_u/kireg_17_u.htm

13. Моніторинг соціально-економічного розвитку регіонів за 2017 рік. URL: http://www.minregion.gov.ua/wpcontent/uploads/2018/03/Otsinka-sotsialno-ekonomichnogorozvitku-regioniv-za-2018-r.-prezentatsiyni-materiali.pdf

14. Офіційний сайт Державного управління статистики України. URL: http://www.ukrstat.gov.ua/, last accessed 2018/10/21

15. Статистичний збірник «Регіони України» 2017. Ч. І. URL: http://www.ukrstat.gov.ua/druk/publicat/kat_u/2017/zb/ 12/zb_ru12017pdf.zip

16. Центр розвитку місцевого самоврядування. URL: http://ofis.odessa.gov.ua/obyednani-gromady-oblasti/

\section{REFERENCES}

Butko, M. P., and Popelo, O. V. "Komertsializatsiia rezultativ naukovo-tekhnichnoi diialnosti $v$ umovakh pohlyblennia intehratsiinykh protsesiv" "Commercialization of results of 
scientific and technical activity in the conditions of deepening of integration processes]. Problemy i perspektyvy ekonomiky ta upravlinnia, no. 1 (2015): 7-20.

"Kapitalni investytsii za rehionamy za 2017 rik" [Capital investment by region for 2017]. http://www.ukrstat.gov.ua/operativ/operativ2016/ibd/iki_reg/iki_reg_u/kireg_17_u.htm

Kukharskaya, N. A. Strategicheskiye prioritety transformatsii ekonomiki regionov Ukrainy: tendentsii, formy, mekhanizmy [Strategic priorities for the transformation of the economy of the regions of Ukraine: trends, forms, mechanisms]. Odessa: IPREEI NAN Ukrainy, 2010.

[Legal Act of Ukraine] (2005). https://zakon.rada.gov.ua/ laws/show/2850-15

"Monitorynh sotsialno-ekonomichnoho rozvytku rehioniv za 2017 rik" [Monitoring of socio-economic development of regions for 2017]. http://www.minregion.gov.ua/ wp-content/uploads/2018/03/Otsinka-sotsialno-ekonomichnogo-rozvitku-regioniv-za-2018-r.-prezentatsiyni-materiali.pdf

Melnik, L. G. Ekonomika razvitiya [Development Economics]. Sumy: Universitetskaya kniga, 2013.

Ofitsiinyi sait Derzhavnoho upravlinnia statystyky Ukrainy. http://www.ukrstat.gov.ua/

Pavlov, V. I. "Polityka rehionalnoho rozvytku v umovakh rynkovoi transformatsii: teoretyko-metodolohichni aspekty ta mekhanizmy realizatsii" [Regional development policy in conditions of market transformation: theoretical and methodological aspects and mechanisms of implementation]: dys. ... d-ra ekon. nauk, 2000.
"Statystychnyi zbirnyk «Rehiony Ukrainy»" [Statistical collection «Regions of Ukraine»], part 1. 2017. http://www.ukrstat. gov.ua/druk/publicat/kat_u/2017/zb/12/zb_ru12017pdf.zip

Stechenko, D. M. Rozmishchennia produktyvnykh syl $i$ rehionalistyka [Deployment of productive forces and regionalism]. Kyiv: Vikar, 2001

"Tsentr rozvytku mistsevoho samovriaduvannia" [Center for Local Self-Government Development]. http://ofis.odessa. gov.ua/obyednani-gromady-oblasti/

Transformatsiia modeli ekonomiky Ukrainy. Ideolohiia, protyrichchia, perspektyvy [Transformation of the model of economy of Ukraine. Ideology, contradictions, perspectives]. Kyiv: Lohos, 1999.

"Valovyi rehionalnyi produkt (2004-2018)" [Gross regional product (2004-2018)]. http://www.ukrstat.gov.ua/operativ/ operativ2008/vvp/vrp/vrp2018_u.zip

Vakhovych, I. M., and Havura, V. O. Formuvannia konkurentospromozhnoi ekonomiky rehioniv Ukrainy [Formation of competitive economy of regions of Ukraine]. Lutsk: Nadstyria, 2013.

Zabarna, E. M. "Strateguvannia yak instrument sotsialnoekonomichnoho rozvytku realnoho sektoru rehioniv" [Strategizing as a tool for socio-economic development of the real sector of the regions]. In Vyperedzhaiuchyi innovatsiinyi rozvytok: teoriia, metodyka, praktyka, 93-115. Sumy: Terytoriia, 2018.

Zabarna, E. M., and Cherednychenko, V. A. “Do pytannia formuvannia pravovykh ta finansovykh peredumov samoupravlinnia rehioniv ta terytorialnykh hromad" [On the formation of legal and financial preconditions for self-government of regions and territorial communities]. Ekonomichnyi forum, no. 1 (2018): 62-67. 